

\section{The Next Economic Disaster}

Why It's Coming and How to Avoid It

\section{Richard Vague}

\section{$\overline{\text { PENN }}$}

UNIVERSITY OF PENNSYLVANIA PRESS

PHILADELPHIA 
Copyright $\odot 2014$ University of Pennsylvania Press

All rights reserved. Except for brief quotations used for purposes of review or scholarly citation, none of this book may be reproduced in any form by any means without written permission from the publisher.

Published by

University of Pennsylvania Press

Philadelphia, Pennsylvania 19104-4112

www.upenn.edu/pennpress

Printed in the United States of America

A Cataloging-in-Publication Record is available from the Library of Congress

Jacket design by John Hubbard

ISBN 978-0-8122-4704-6

eISBN 978-0-8122-9110-0 